\title{
12. UPPER MAESTRICHTIAN AND PALEOCENE PLANKTONIC FORAMINIFERAL BIOSTRATIGRAPHY OF THE NORTHERN CAPE BASIN, DEEP SEA DRILLING PROJECT HOLE 5241
}

\author{
C. C. Smith, ${ }^{2}$ U.S. Geological Survey, Washington, D.C. \\ and \\ R. Z. Poore, U.S. Geological Survey, Reston, Virginia
}

\begin{abstract}
Examination of Maestrichtian and Paleocene planktonic foraminiferal assemblages from DSDP Leg 73, Hole 524, revealed an expanded and apparently continuous sequence of sediments across the Cretaceous/Tertiary boundary. Within the Upper Cretaceous section, Core 28 is assigned to the upper part of the Globotruncana gansseri Subzone of late middle Maestrichtian age, and Cores 27 through 21 are assigned to the Abathomphalus mayaroensis Subzone of late Maestrichtian age. The lower portion of Core 20 is assigned to the "Globigerina eugubina" Zone, and the upper part of Core 20 is assigned to the Subbotina pseudobulloides Zone. Integration of these data with the Cretaceous/Tertiary boundary in Hole 524 as defined by calcareous nannofossil biostratigraphy indicates that part of the "G. eugubina" Zone is of late Maestrichtian rather than early Danian age. Paleomagnetic analysis of Hole 524 shows that the paleontologic Cretaceous/Tertiary boundary occurs in the reversed portion of Chron C-29.
\end{abstract}

\section{INTRODUCTION}

Site 524 is located in the northern Cape Basin on a submarine fan derived from a submarine canyon cut into the Walvis Ridge $\left(29^{\circ} 29^{\prime} \mathrm{S}, 3^{\circ} 31^{\prime} \mathrm{E}\right.$; water depth, $4796 \mathrm{~m}$.). Three holes were cored at Site 524. Hole 524, which was drilled with conventional rotary techniques, was spot cored in the upper $47.5 \mathrm{~m}$ and then continuously cored below $47.5 \mathrm{~m}$ sub-bottom. In Hole 524A, two conventional cores were recovered from the top of the sedimentary section. In Hole 524B, which was offset $100 \mathrm{ft}$. from Hole 524A, attempts were made to acquire seven cores with the hydraulic piston corer (HPC). Core recovery was erratic, however, and coring disturbance was common. The cores recovered from Hole 524A and Cores 1 through 3 of Hole 524 were also too disturbed for magnetic polarity analysis. Cores 4 through 28 of Hole 524, however, recovered an expanded sedimentary section that yielded a reliable magnetic polarity record and contained stratigraphically diagnostic planktonic foraminifers. The purpose of this contribution is to establish the occurrence of the stratigraphically diagnostic foraminifers in Cores 4 through 28 of Hole 524 and to discuss the rationale for the age and zone assignments.

\section{HOLE 524 SEDIMENTS}

The sediments recovered in Cores 4 through 28 of Hole 524 vary from nannofossil chalk and marl to claystone to bioclastic and volcaniclastic sandstones. Turbidites derived from the nearby Walvis Ridge comprise much of the section, and the large turbidite component results in an average accumulation rate of about 30 $\mathrm{m} / \mathrm{m}$.y. Reworking was noted in many samples, and

\footnotetext{
${ }^{1}$ Hsü, K. J., LaBrecque, J. L., et al., Init. Repts. DSDP, 73: Washington (U.S. Govt. Printing Office).

2 Present address: Tenneco Oil Co., Houston, Texas.
}

foraminifers are poorly preserved in several intervals. Because of the problems with reworking and preservation, the section from Hole 524 was sampled only in enough detail to provide a basis for the correlation of the foraminiferal biostratigraphy with the magnetic polarity record. The correlation between the magnetostratigraphy and biostratigraphy in Hole 524 is summarized by Poore et al. (this vol.).

The stratigraphic occurrences of the foraminiferal taxa identified in Hole 524 samples are plotted in Table 1. Abundance estimates were derived by examining washed residues equal to or greater than $63 \mu \mathrm{m}$ in size. The categories used in Table 1 are defined as follows in terms of the number of specimens per sample: VR (very rare) -1 to 2 ; $R$ (rare) -3 to 5 ; $\mathrm{C}$ (common)6 to 10; A (abundant)-11 to 50; and VA (very abundant) -50 or more.

The foraminiferal zonations follow Pessagno (1967) for the Cretaceous and Stainforth et al. (1975) for the Paleocene.

\section{Maestrichtian Biostratigraphy}

The planktonic foraminifers recovered from the Maestrichtian section of Hole 524 vary considerably in occurrence and relative abundance (Table 1), with obvious indications of reworking particularly prevalent at and near the Maestrichtian/Danian boundary. The lowermost sample observed to contain Cretaceous planktonic foraminifers was Sample 28,CC, which yielded very rare individuals of Heterohelix glabrans (Cushman). Underlying sediments (Samples 524-29-1, 55-57 cm, 524$29, \mathrm{CC}$, and $524-32-2,54-56 \mathrm{~cm}$ ) proved to be barren of planktonic foraminifers. The presence of $H$. glabrans (Cushman) in Sample 28,CC, as well as the fauna recovered from overlying samples in Core 28 , including Planoglobulina brazoensis Martin, plicate Globotruncana contusa (Cushman), and the very rare presence of 
Table 1. Occurrence and relative abundance of planktonic foraminifers in Cores 4 to 32 of Hole 524 .

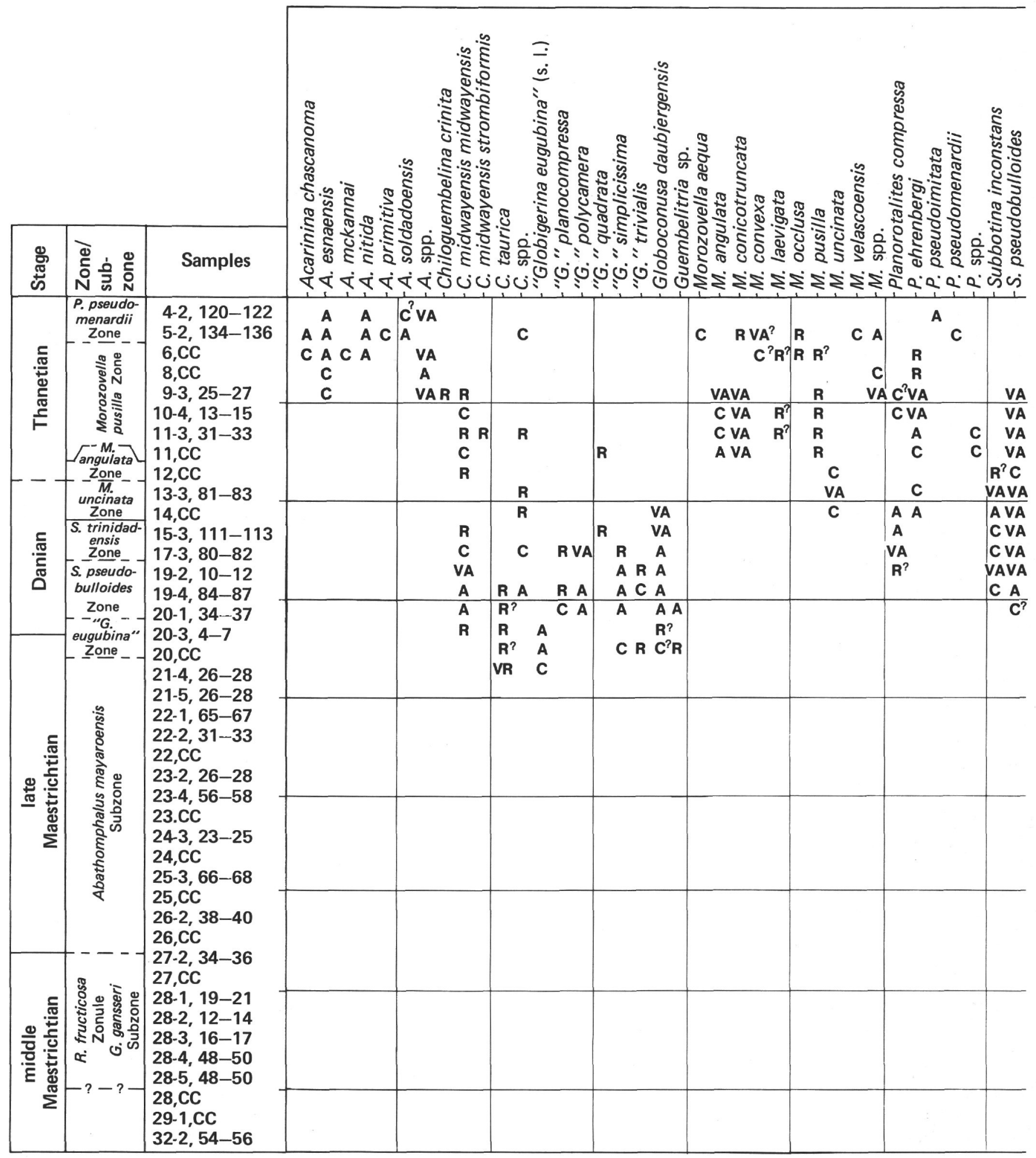

Abathomphalus intermedius (Bolli), indicates that the majority of Core 28 can be assigned to the Racemiguembelina fructicosa Zonule of Smith and Pessagno (1973), the upper part of the G. gansseri Subzone, of late middle Maestrichtian age.

Within the framework of the present investigation, the boundary between the middle Maestrichtian G. gans- seri Subzone and overlying late Maestrichtian A. mayaroensis Subzone cannot be precisely resolved because of the absence or low diversity and nondiagnostic nature of the planktonic foraminifers in the section immediately overlying Sample 524-28-2, 12-14 cm. Until a more comprehensive study can be undertaken, the planktonic foraminiferal middle/late Maestrichtian boundary can 
Table 1. (Continued).

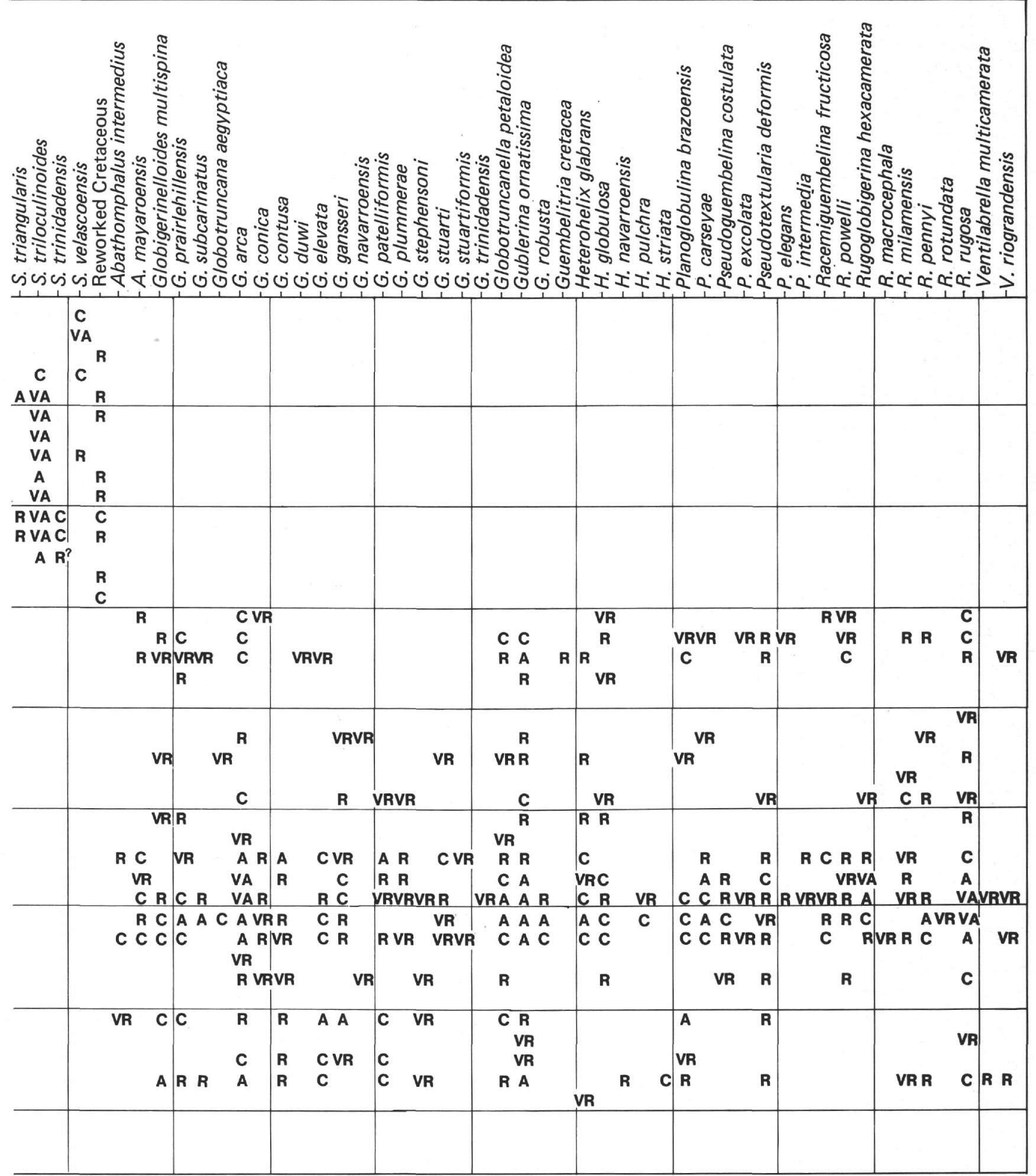

only be defined as lying within the interval between Sample 524-28-2, 12-14 cm and Sample 524-26,CC.

The abundant, diverse, and well preserved planktonic foraminiferal fauna recovered from Sample 26,CC through Core 21 is herein assigned to the $A$. mayaroensis Subzone, which is late Maestrichtian in age. The fauna within this interval contains typical and morphologically advanced forms of $R$. fructicosa, rare individuals of $G$. conica, morphologically advanced and very highly plicate $G$. contusa, rare to common individuals of $G$. stuarti, and both $A$. intermedius and rare to common large and well developed $A$. mayaroensis. 
Late Maestrichtian planktonic foraminifers extend upward from Core 27 through Core 20 and continue to be present sporadically as high as Core 6 . These Maestrichtian species (see Table 1) co-occur with undeniable Danian species in the upper part of Core 20, and a progressively younger Paleocene fauna up through Core 6. Intensive and detailed investigations of the calcareous nannofossil flora from Hole 524 by Percival (this vol.) have found that the Cretaceous/Tertiary boundary is at Sample 524-20-3, $105 \mathrm{~cm}$. Thus, it seems evident that the late Maestrichtian fauna in the upper part of Core 20 through Core 6 has been either reworked in situ into overlying sediments of early Paleocene age or that the mixed foraminiferal fauna is the result of paleoslope instability and turbidite activity. In either case, the highest occurrence of undeniable Upper Cretaceous species cannot be used as a reliable guide in marking the Maestrichtian/Danian boundary in Hole 524.

\section{Paleocene Biostratigraphy}

Indications of Paleocene taxa are first seen in Sample 524-21-4, 26-28 cm, where minute representatives of "Globigerina eugubina" (s.1.) Luterbacher and Premoli Silva occur with Chiloguembelina taurica Morozova. Most of the individuals included in "G. eugubina" (s.1.) are morphologically similar to "G. fringa" Subbotina (see Plate 1). Additions to the "Paleocene" fauna in the lower part of Core 20 (Samples 524-20,CC and 524-20-3, 4-7 cm) include "G. simplicissima" (Blow) and forms very close to Globoconusa daubjergensis (Brönnimann). Sample 524-20-1, 34-37 cm contains typical G. daubjergensis and forms similar to Subbotina pseudobulloides (Plummer), whereas S. inconstans (Subbotina) and typical S. pseudobulloides are present in samples from Core 19. Cretaceous planktonic foraminifers occur in all samples from Cores 21 and 20 but are rare in Sample 524-20-1, 34-37 cm.

The zonation of assemblages from Cores 21 and 20 is equivocal. The fauna from the top of Core 20 is too advanced and diverse to be of basal Danian age and is assigned to the $S$. pseudobulloides Zone. The lower part of Core 20 is assigned to the "Globigerina eugubina" Zone, and Core 21 is assigned to the Abathomphalus mayaroensis Subzone. Alternatively, the occurrence of "G. eugubina" and C. taurica in Sample 524-21-4, 26-28 cm could be used to assign most of Core 21 to the "G. eugubina" Zone.

Detailed study of calcareous nannofossils in Hole 524 (Percival, this vol.; Hsü et al., 1982) indicates that the Cretaceous/Tertiary boundary occurs at $105 \mathrm{~cm}$ in Section 3 of Core 20. Placement of the Cretaceous/Tertiary boundary at this level is supported by the presence of an iridium anomaly (Hsü et al., 1982). Thus, data from Hole 524 indicate that "Globigerina eugubina" (s.1.) and $C$. taurica range down into the Cretaceous.

The assemblage from Sample 524-17-3, 80-82 cm contains specimens similar to $S$. trinidadensis, and this occurrence is used to approximate the lower limit of the $S$. trinidadensis Zone. S. trinidadensis is not well developed in Hole 524 assemblages, however, and an alternative interpretation would be to use the occurrence of
S. inconstans in Core 19 to approximate the base of the S. trinidadensis Zone between Cores 19 and 20 .

S. pseudobulloides and S. triloculinoides (Plummer) are consistently abundant in assemblages from Cores 17 through 12. The lowest occurrences of Morozovella uncinata (Bolli), M. pusilla (Bolli), and Planorotalites pseudomenardii (Bolli) mark the lower limits of the $M$. uncinata, $M$. pusilla, and $P$. pseudomenardii Zones. Note that $M$. angulata (White), $M$. conicotruncata (Subbotina), and M. pusilla (Bolli) all have their lowest occurrence in Sample 11,CC. Rather than presume an unconformity, we infer that the $M$. angulata Zone is present in the unsampled interval of Core 12. M. conicotruncata is a prominent component of the diverse assemblages from Cores 11 through 9. Planktonic foraminiferal assemblages in Cores 8 through 4 are generally poorly preserved and are dominated by small representatives of Acarinina. Planorotalites is not well represented in these assemblages, and thus the base of the $P$. pseudomenardii Zone may actually occur lower in the section.

\section{SUMMARY}

An expanded and apparently continuous section from the Maestrichtian Globotruncana gansseri Subzone to the Paleocene Planorotalites pseudomenardii Zone was recovered in DSDP Hole 524. With the exception of the Morozovella angulata Zone, all of the standard lowlatitude foraminiferal zones are recognized; the $M$. angulata Zone is inferred to occur in an unsampled interval. Although the precise positions of several boundaries are cannot be determined, data from Hole 524 allow the direct calibration of standard foraminiferal zonations to latest Cretaceous and Paleocene magnetic polarity history.

\section{REFERENCES}

Beckman, J. P., 1957. Chiloguembelina Loeblich and Tappan and related Foraminifera from the lower Tertiary of Trinidad, B.W.I. U.S. Nat. Mus. Bull., 215:83-95.

Berggren, W. A., 1977. Atlas of Palaeogene planktonic Foraminifera. In Ramay, A. T. S. (Ed.), Oceanic Micropalaeontology (Vol. 1): London (Academic Press Inc.), 205-300.

Blow, W. H., 1979. The Cainozoic Globigerinida: Leiden (E. J. Brill).

Bolli, H. M., 1951. The genus Globotruncana in Trinidad, B.W.I. J. Paleontol., 25:187-199.

1957. The genera Globigerina and Globorotalia in the Paleocene-Lower Eocene Lizard Springs Formation of Trinidad, B. W. I. U.S. Nat. Mus. Bull., 215:61-81.

Brönnimann, P., 1952a. Globigerinidae from the Upper Cretaceous (Cenomanian-Maestrichtian) of Trinidad, B. W. I. Bull. Am. Paleontol., 34:5-50. 1952b. Trinidad Paleocene and Lower Eocene Globigerinidae. Bull. Am. Paleontol., 34:1-35. 1953. Note on planktonic Foraminifera from Danian localities of Jutland, Denmark. Eclogae Geol. Helv., 45:339-341.

Brotzen, F., 1934. Foraminiferen aus dem Senon Palastinas. Dtsch. Ver. Palästinas, 57:28-72.

1936. Foraminiferen aus dem schwedischen untersten Senon von Eriksdal in Schonen. Sver. Geol. Unterst., 396:1-206.

Cushman, J. A., 1925. Some new Foraminifera from the Velasco Shale of Mexico. Contrib. Cushman Lab. Foraminiferal Res., 1: 18-23.

1926. Some Foraminifera from the Mendez Shale of eastern Mexico. Contrib. Cushman Lab. Foraminiferal Res., 2:16-26. 1933. Some new foraminiferal genera. Contrib. Cushman Lab. Foraminiferal Res., 9:32-38. 
1938. Cretaceous species of Gumbelina and related genera. Contrib. Cushman Lab. Foraminiferal Res., 14:2-28.

1940. Midway Foraminifera from Alabama. Contrib. Cushman Lab. Foraminiferal Res., 16:51-73.

1946. Upper Cretaceous foraminifera of the Gulf Coastal region of the United States and adjacent areas. Geol. Surv. Prof. Pap. U.S., 206:1-241.

Cushman, J. A., and Church, C. C., 1929. Some Upper Cretaceous foraminifera from near Coalinga, California. Proc. Calif. Acad. Sci., 18:497-530.

Cushman, J. A., and Renz, H. H., 1942. Eocene, Midway, Foraminifera from Soldado Rock, Trinidad. Contrib. Cushman Lab. Foraminiferal Res., 18:1-20.

Dalbiez, F., 1955. The genus Globotruncana in Tunisia. Micropaleontology, 1:161-171.

de Klasz, I., 1953. Einige neue oder wenig bekannte Foraminiferen aus der helvetischen Oberkreide der bayerischen Alpen südlich Traunstein (Oberbayern). Geol. Bavarica, 17:233-244.

de Lapparent, J., 1918. Étude lithologique des terrains Crétaces de la region d'Hendaye, Serv. Carte Geol. Fr. Mem.: 1-153.

Egger, J. G., 1899. Foraminiferen und ostrakoden aus den Kreidemergeln der oberbayerischen Alpen. K. Bayer Akad. Wiss., München, Math.-Phys. Ci, 21:3-230.

Ehrenberg, C. G., 1840. Die bildung der Europaischen, Libyschen und Arabischen Kreidefelsen und des Kreidemergels aus mikroskopischen Organismen. Abh. Preuss. Akad. Wiss., München, pp. $1-91$.

Finlay, H. J., 1947. New Zealand Foraminifera: key species in stratigraphy. N. Z. J. Sci. Technol., B28, 5:259-292.

Gandolfi, R., 1955. The genus Globotruncana in northeastern Colombia. Bull. Am. Paleontol., 36:7-118.

Glaessner, M. F., 1937. Studien über Foraminiferen aus der Kreide und dem Tertiär des Kaukasus. Probl. Paleontol., Moscow Univ. Lab. Paleontol., 2-3:349-410.

Hsü, K. J., He, Q., McKenzie, J. A., Weissert H., Perch-Nielsen, K., Oberhänsli, H., Kelts, K., LaBrecque, J., Tauxe, L., Krähenbühl, U., Percival, S. F., Wright, R., Karpoff, A., Petersen, N., Tucker, P., Poore, R., Gombos, A., Pisciotto, K., Carman, M. F., and Schreiber, E., 1982. Mass mortality and its environmental and evolutionary consequences. Science, 216:249-256.

Khalilov, D. M., 1956. O pelagicheskoj faune foraminifer Paleogenovykh otlozhenij Azerbajdzhana. Akad. Nauk Azerbaidzhan, 17: 234-255.

Kikoine, J., 1948. Les Heterohelicidae du Crétace superieur pyrénéen. Bull. Soc. Géol. Fr., 18:15-35.

Krasheninnikov, V. A., and Hoskins, R. H., 1973. Late Cretaceous Paleogene and Neogene planktonic foraminifera. In Heezen, B. C., MacGregor, I. D., et al., Init. Repts. DSDP, 20: Washington (U.S. Govt. Printing Office), 105-203.

Lalicker, C. G., 1948. A new genus of foraminifera from the Upper Cretaceous. J. Paleontol., 22:624.

LeRoy, L. W., 1953. Biostratigraphy of the Maqfi section, Egypt. Mem. Geol. Soc. Am. 54:1-73.

Loeblich, A. R., Jr., 1951. Coiling in the Heterohelicidae. Contrib. Cushman Found. Foraminiferal Res., 18:106-111.

Loeblich, A. R., Jr., and Tappan, H., 1957. Planktonic Foraminifera of Paleocene and early Eocene age from the Gulf and Atlantic Coastal Plains. U.S. Nat. Mus. Bull., 215:173-198.

Lowrie, W., and Alvarez, W., 1977. Upper Cretaceous-Paleocene magnetic stratigraphy at Gubbio, Italy. III. Upper Cretaceous magnetic stratigraphy. Geol. Soc. Am. Bull, 88:374-377.

Luterbacher, H., and Premoli Silva, I., 1964. Biostratigrafia del limite Cretaceo-Terziario nell'Appennino centrale. Riv. Ital. Paleontol. Stratigraf., 70:67-128.

Martin, L. T., 1943. Eocene Foraminifera from the type Lodo Formation, Fresno County, California. Stanford Univ. Publ. Geol. Sci., 3:93-125.

Martin, S. E., 1972. Reexamination of the Upper Cretaceous planktonic foraminiferal genus Planoglobulina Cushman and Ventilabrella Cushman. J. Foraminiferal Res., 2:73-92.

Morozova, V. G., and Moskalenko, T. A., 1961. Foraminifères planctoniques des dépôts limitrophes du Bajocien et du Daghestan central (nord-est du Caucase). Acad. Nauk. SSR Vopr. Mikropaleontol., 5:3-30.
Nakkady, S. E., 1950. A new foraminiferal fauna from the Esna Shales and Upper Cretaceous Chalk of Egypt. J. Paleontol., 24: 675-692.

Pessagno, E. A., Jr., 1967. Upper Cretaceous planktonic foraminifera from the western Gulf Coastal Plain. Paleontographica Americana, 5:245-445.

Plummer, H. J., 1926. Foraminifera of the Midway Formation in Texas. Univ. Tex. Bull., 2644:1-206.

1931. Some Cretaceous foraminifera in Texas. Univ. Tex. Bull., 3101:109-203.

Premoli Silva, I., and Bolli, H. M., 1973. Late Cretaceous to Eocene planktonic foraminifera and stratigraphy of the Leg 15 sites in the Caribbean Sea. In Edgar, N. T., Saunders, J. B., et al., Init. Repts. DSDP, 15: Washington (U.S. Govt. Printing Office), 499-547.

Rzehak, A., 1891. Die Foraminiferenfauna der alttertiären Ablagerungen von Bruderndorf in Niderösterreich, mit Berücksichtigung des angeblichen Kreidevorkommens von Leitzerdorf. $\mathrm{K} . \mathrm{K} . \mathrm{Na}$ turh. Hofmus., Ann., 6:1-12.

1895. Über einige merkwürdige Foraminiferen aus dem österreichischen Tertiär. K. K. Naturh. Hofmus., Ann., 10:213-230.

Schutzkaja, E. K., 1965. Filogeneticheskie uzaimootnosheniya vidov gruppy Globorotalia planocompressa Plummer v datskom veke i paleotsenory epokhe. Akad. Nauk SSSR Vopr. Mikropaleont., 9:173-187.

Smith, C. C., and Pessagno, E. A., Jr., 1973. Planktonic foraminifera and stratigraphy of the Corsicana Formation (Maestrichtian) North-Central Texas. Cushman Found. Foraminiferal Res. Spec. Publ. 12:1-68.

Stainforth, R. M., et al., 1975. Cenozoic planktonic foraminiferal zonation and characteristics of index forms. Univ. Kan. Paleontolog. Contrib., 62:1-425.

Subbotina, N. N., 1947. Foraminifery datskikh i paleogenovikh otlozhenii severnogo Kavkaza: Mikrofauna Kavkaza, Emby i sryednei Azii. Tr. Vses. Neft. Nauchno-Issled. Geologorazved. Inst., 39-160. 1953. Globigerinidy, Khantkhennidy i Globorotaliidy. $T r$. Vses. Neft. Nauchno-Issled. Geologorazved. Inst., 76:1-294.

White, M. P., 1928. Some index Foraminifera of the Tampico embayment area of Mexico. J. Paleontol., 2:177-215, 280-317.

Date of Initial Receipt: August 13, 1982

APPENDIX

Taxonomic Notes

The original references to all taxa identified and plotted in Table 1 are listed below. Comments are provided for selected taxa. Genera and included species are listed in alphabetical order. The classification of lower Tertiary planktonic foraminifers is not well established. The Tertiary ad hoc taxonomy used in this study incorporates elements of new classification schemes (e.g., Berggren, 1977) in more conservative systems (e.g., Bolli, 1957). The classification and taxonomic concepts for the Upper Cretaceous taxa are those of Pessagno (1967) and Smith and Pessagno (1973).

Paleocene Taxa

$$
\text { Acarinina chascanoma (Loeblich and Tappan) }
$$

Globigerina chascanona Loeblich and Tappan, 1957, p. 180, pl. 49, figs. 4 , 5; pl. 61 , fig. 8 .

\section{Acarinina esnaensis (LeRoy)}

Globigerina esnaensis LeRoy, 1953, p. 31, pl. 6, figs. 8-10.

Acarinina mckannai (White)

Globigerina mckannai White, 1928, p. 194, pl. 27, fig. 16 .

Acarinina nitida (Martin)

Globigerina nitida Martin, 1943, p. 25, pl. 7, fig. 1.

\section{Acarinina primitiva (Finlay)}

Globoquadrina primitiva Finlay, 1947, p. 291, pl. 8, figs. 129-134.

Several authors, for example Berggren (1977), include Acarinina primitiva and $A$. triplex Subbotina with $A$. coalingensis (Cushman 
and Hanna). In this study $A$. primitiva is used for these compact forms because the concept of $A$. primitiva is well established in the literature with excellent illustrations and adequate descriptions.

\section{Acarinina soldadoensis (Brönnimann)}

Globigerina soldadoensis Brönnimann, 1952b, p. 7, pl. 1, figs. 1-9.

Chiloguembelina crinita (Glaessner)

Gumbelina crinita Glaessner, 1937, p. 383, pl. 4, fig. 34.

Chiloguembelina midwayensis midwayensis (Cushman)

Gumbelina midwayensis Cushman, 1940, p. 65, pl. 11, fig. 15.

Chiloguembelina midwayensis strombiformis Beckmann

Chiloguembelina midwayensis strombiformis Beckmann, 1957, p. 90, pl. 21, fig. 6; text-figs. 14, 28-31.

\section{Chiloguembelina taurica Morozova}

Chiloguembelina taurica Morozova and Moskalenko, 1961, p. 18, pl. 1 , figs. 7,8 .

“Globigerina eugubina" Luterbacher and Premoli Silva (s.l.) (Plate 1, Figs. 1-10)

Globigerina eugubina Luterbacher and Premoli Silva, 1964, p. 105, pl. 2, fig. 8.

Minute, four-to six-chambered forms found in Cores 21 and 20 of Hole 524 are referred to "Globigerina eugubina" (s.1.). Many specimens resemble $G$. fringa Subbotina as illustrated by Premoli Silva and Bolli $(1973$, pl. 7) and $G$. sabina Luterbacher and Premoli Silva as illustrated by Krasheninnikov and Hoskins (1973, pl. 11). The specimens from Hole 524 exhibit a well defined lip. In many of the compact and tightly coiled specimens the lip covers the umbilical region completely (e.g., Plate 1, Figs. 4 and 8) or almost completely (e.g., Plate 1, Fig. 5). In forms with more spherical chambers, the lip protrudes part of the way over an open, deep umbilical pit (e.g., Plate 1, Figs. 6 and 7). Calcite pustules or tubercles are developed between pores on the test surface. In some specimens (e.g., Plate 1, Fig. 6) the pustules begin to coalesce and show incipient formation of the honeycomb or reticulate surface texture typical of the genus Subbotina. No indications of spines were seen on any specimens.

A number of studies (e.g., Lowrie and Alvarez, 1977) have established that the Cretaceous/Tertiary boundary occurs in the upper part of the reversed subchron of magnetic Chron C-29. The lowest occurrence of "G. eugubina" s.1. in Sample 524-21-4, 26-28 cm falls in the top of the normal subchron of Chron C-30. Thus, regardless of one's taxonomic interpretations, the data from Hole 524 indicate that taxa characteristic of the "G. eugubina" Zone occur in sediments of latest Cretaceous age.

\section{“Globigerina planocompressa" (Shutskaya)}

Globorotalia planocompressa planocompressa Shutskaya, 1965, p. 180 , pl. 1, fig. 6.

\section{“Globigerina polycamera" Khalilov}

Globigerina edita polycamera Khalilov, 1956, p. 235, pl. 1, fig. 1.

\section{"Globigerina quadrata" White}

Globigerina quadrata White, 1928, p. 195, pl. 27, fig. 18.

\section{“Globigerina" simplicissima (Blow)}

Eoglobigerina eobulloides simplicissima Blow, 1979, p. 1217, pl. 55, figs. 1-4; pl. 57, figs. 3, 4; pl. 60, figs. 2, 3; pl. 70, figs. 5, 6, 9, 10; pl. 73 , figs. $1-3,8,9$.

"Globigerina simplicissima" is used for specimens exhibiting somewhat radially elongated and separated chambers with a well defined lip (e.g., Blow, 1979, pl. 60, fig. 2, and pl. 70, fig. 9).

\section{"Globigerina" trivialis Subbotina}

Globigerina trivialis Subbotina, 1953, p. 64, pl. 4, figs. 4-8.
Globoconusa daubjergensis (Brönnimann)

Globigerina daubjergensis Brönnimann, 1953, p. 340, fig. 1.

Morozovella aequa (Cushman and Renz)

Globorotalia crassata aequa Cushman and Renz, 1942, p. 12, pl. 3, fig. 3.

Morozovella angulata (White)

Globigerina angulata White, 1928, p. 191, pl. 27, fig. 13.

Morozovella conicotruncata (Subbotina)

Globorotalia conicotruncata Subbotina, 1947, p. 115, pl. 4, figs. 11-13; pl. 9, figs. 9-11.

Morozovella convexa (Subbotina)

Globorotalia convexa Subbotina, 1953, p. 209, pl. 17, fig. 2.

Morozovella laevigata (Bolli)

Globorotalia pusilla laevigata Bolli, 1957, p. 78, pl. 20, figs. 5-7.

Morozovella occlusa (Loeblich and Tappan)

Globorotalia occlusa Loeblich and Tappan, 1957, p. 190, pl. 55, fig. 3; pl. 64, fig. 3 .

Morozovella pusilla (Bolli)

Globorotalia pusilla pusilla Bolli, 1957, p. 78, pl. 20, figs. 8-10.

Morozovella uncinata (Bolli)

Globorotalia uncinata Bolli, 1957, p. 74, pl. 17, figs. 13-15.

Morozovella velascoensis (Cushman)

Pulvinulina velascoensis Cushman, 1925, p. 19, pl. 3, fig. 5.

Planorotalites compressa (Plummer)

Globigerina compressa Plummer, 1926, p. 135, pl. 8, fig. 11.

Planorotalites ehrenbergi (Bolli)

Globorotalia ehrenbergi Bolli, 1957, p. 77, pl. 20, figs. 18-20.

Planorotalites pseudoimitata (Blow)

Globorotalia pseudoimitata Blow, 1979, p. 1104, pl. 101, figs. 1-3; pl. 106, figs. 2-10; pl. 108, figs. 1-3.

\section{Planorotalites pseudomenardii (Bolli)}

Globorotalia pseudomenardii Bolli, 1957, p. 77, pl. 20, figs. 14-17.

Subbotina inconstans (Subbotina)

Globigerina inconstans Subbotina, 1953, p. 58, pl. 3, figs. 1, 2.

Subbotina pseudobulloides (Plummer)

Globigerina pseudobulloides Plummer, 1926, p. 33, pl. 8, fig. 9.

\section{Subbotina triangularis (White)}

Globigerina triangularis White, 1928, p. 195, pl. 28, fig. 1.

Subbotina triloculinoides (Plummer)

Globigerina triloculinoides Plummer, 1926, p. 134, pl. 8, fig. 10.

\section{Subbotina trinidadensis (Bolli)}

Globorotalia trinidadensis Bolli, 1957, p. 73, pl. 16, figs. 19-23.

It was difficult to recognize Subbotina trinidadensis in the Hole 524 assemblages. Examination of the holotype and paratypes indicates that the concept of $S$. trinidadensis covers a broad range of forms that extends from $S$. praecursoria (Morozova) to $S$. inconstans (Subbotina). For example, one of the paratypes of $S$. trinidadensis has five chambers in the ultimate whorl and appears to be a good match for 
the specimens of $S$. inconstans illustrated by scanning electron microscope by Stainforth et al. (1975). The lack of clearly diagnostic characteristics for $\boldsymbol{S}$. trinidadensis diminish its value as a zonal marker.

Subbotina velascoensis (Cushman)

Globigerina velascoensis Cushman, 1925, p. 19, pl. 3, fig. 6.

Maestrichtian Taxa

Abathomphalus intermedius (Bolli)

Globotruncana intermedia Bolli, 1951, pp. 197-198, pl. 35, figs. 7-9.

Abathomphalus mayaroensis (Bolli)

Globotruncana mayaroensis Bolli, 1951, p. 198, pl. 35, figs. 10-12.

Globigerinelloides multispina (Lalicker)

Biglobigerinella multispina Lalicker, 1948, p. 624, pl. 92, figs. 1a-c, $2 a-b, 3 a-c$.

\section{Globigerinelloides prairiehillensis Pessagno}

Globigerinelloides prairiehillensis Pessagno, 1967, pp. 277-278, pl. 60 , figs. 2-3; pl. 83, fig. 1; pl. 90, figs. 1-2, 4; pl. 97, figs. 3, 4 .

Globigerinelloides subcarinatus (Brönnimann)

Globigerinella messinae subcarinata Brönnimann, 1952a, pp. 44-45, pl. 1, figs. 10-11; text-figs. 21a-m.

\section{Globotruncana aegyptiaca Nakkady}

Globotruncana aegyptiaca Nakkady, 1950, p. 690, pl. 90, figs. 20, 21, 22.

Globotruncana arca (Cushman)

Pulvinulina arca Cushman, 1926, p. 23, pl. 3, figs. 1a-c.

Globotruncana conica White

Globotruncana conica White, 1928, p. 285, pl. 38, figs. 7a-c.

\section{Globotruncana contusa (Cushman)}

Pulvinulina arca contusa Cushman, 1926, p. 23.

Globotruncana arca contusa Cushman, 1946, pp. 150-151, pl. 26, figs. $6 a-b$.

\section{Globotruncana duwi Nakkady}

Globotruncana aegyptaiaca duwi Nakkady, 1950, p. 690, pl. 90, figs. $17,18,19$.

\section{Globotruncana elevata (Brotzen)}

Rotalia elevata Brotzen, 1934, p. 66, pl. 3, fig. C.

The description and discussion presented by Pessagno (1967, pp. 336-337) and Smith and Pessagno (1973, pp. 47-48) is followed herein. These authors disagree with the inclusion of Globotruncana stuartiformis Dalbiez as a junior synonym of $G$. elevata. The most significant feature in the separation of these species is the much more umbilicoconvex nature of $G$. elevata.

\section{Globotruncana gansseri Bolli}

Globotruncana gansseri Bolli, 1951, pp. 196-197, pl. 35, figs. 1-3.

Globotruncana navarroensis Smith and Pessagno

Globotruncana navarroensis Smith and Pessagno, 1973, pp. 49-50, pl. 22, figs. 1-3, 4-5, 6-8, 9-10.

\section{Globotruncana patelliformis Gandolfi}

Globotruncana contusa patelliformis Gandolfi, 1955, pp. 54-55, pl. 4, figs. 2a-c.

\section{Globotruncana plummerae Gandolfi}

Globotruncana fornicata plummerae Gandolfi, 1955, p. 42, pl. 2, figs. 3a-c, 4a-c.

\section{Globotruncana stephensoni Pessagno}

Globotruncana stephensoni Pessagno, 1967, pp. 354-356, pl. 69, figs. 1-3, 4-6, 7-9; pl. 96, figs. 5, 6.

Globotruncana stuarti (de Lapparent)

Rosalina stuarti de Lapparent, 1918, p. 11, pl. 1, figs. 5, 6, 7; text-fig. 4 (p. 12); text-fig. 5a, b, ?c (p. 13).

\section{Globotruncana stuartiformis Dalbiez}

Globotruncana (Globotruncana) elevata stuartiformis Dalbiez, 1955, p. 169 , text-figs. 10a-c.

\section{Globotruncana trinidadensis Gandolfi}

Globotruncana calciformis trinidadensis Gandolfi, 1955, p. 47, pl. 3, figs. $2 a-c$.

Globotruncanella petaloidea (Gandolfi)

Globotruncana petaloidea petaloidea Gandolfi, 1955, p. 52, pl. 3, figs. 13a-c.

\section{Gublerina ornatissima (Cushman and Church)}

Ventilabrella ornatissima Cushman and Church, 1929, p. 512, pl. 39 , figs. 12-15.

\section{Gublerina robusta de Klasz}

Gublerina acuta robusta de Klasz, 1953, p. 247, pl. 8, figs. 4a-b, 5a-b.

\section{Guembelitria cretacea Cushman}

Guembelitria cretacea Cushman, 1933, pp. 37-38, pl. 4, figs. 12a-b.

Heterohelix glabrans (Cushman)

Guembelina glabrans Cushman, 1938, p. 15, pl. 3, figs. 1a-b, 2.

Heterohelix globulosa (Ehrenberg)

Textilaria globulosa Ehrenberg, 1840, p. 135, pl. 4, figs. 2b, 4b, 5b, $7 \mathrm{~b}, 8 \mathrm{~b}$.

\section{Heterohelix navarroensis Loeblich}

Heterohelix navarroensis Loeblich, 1951, pp. 107-108, pl. 12, figs. 1, 2, 3a-b; text-fig. 2.

\section{Heterohelix pulchra (Brotzen)}

Guembelina pulchra Brotzen, 1936, p. 121, pl. 9, figs. 3a-b; not figs. $2 \mathrm{a}-\mathrm{b}$.

\section{Heterohelix striata (Ehrenberg)}

Textilaria striata Ehrenberg, 1840 , p. 135, pl. 4 , figs. $1 \alpha, 1 \alpha^{\prime}, 2 \alpha$, $3 \alpha$; not fig. $9 \alpha$.

\section{Planoglobulina brazoensis Martin}

Planoglobulina brazoensis Martin, 1972, pp. 82-83, pl. 3, figs. 7a-c; pl. 4, figs. 1a-b, 2.

\section{Planoglobulina carseyae (Plummer)}

Ventilabrella carseyae Plummer, 1931, pp. 178-179, pl. 9, figs. 7a-c, $8 \mathrm{a}-\mathrm{b}, 9 \mathrm{a}-\mathrm{c}$; not fig. 10.

\section{Pseudoguembelina costulata (Cushman)}

Guembelina costulata Cushman, 1938, pp. 16-17, pl. 3, figs. 7a-b, 8, 9.

\section{Pseudoguembelina excolata (Cushman)}

Guembelina excolata Cushman, 1926, p. 20, pl. 2, fig. 9.

Pseudotextularia deformis (Kikoine)

Guembelina striata deformis Kikoine, 1948, p. 20, pl. 1, figs. 8a-c. 


\section{Pseudotextularia elegans (Rzehak)}

Cuneolina elegans Rzehak, 1891, p. 4.

Pseudotextularia varians Rzehak, 1895, p. 217, pl. 7, figs. 1a-b; not figs. 2, 3 .

\section{Pseudotextularia intermedia de Klasz}

Pseudotextularia intermedia de Klasz, 1953, p. 231, pl. 5, figs. 2a-c. This species was rarely observed in the lower part of the late Maestrichtian Abathomphalus mayaroensis Subzone at Site 524. Although not observed in the upper part of the middle Maestrichtian Globotruncana gansseri Subzone, it probably has an earlier biostratigraphic history (as noted by Pessagno, 1967, p. 269).

\section{Racemiguembelina fructicosa (Egger)}

Guembelina fructicosa Egger, 1899, p. 35, pl. 14, figs. 8-9; not figs. $24,25-26$.

\section{Racemiguembelina powelli Smith and Pessagno}

Racemiguembelina powelli Smith and Pessagno, 1973, pp. 35-36, pl. 11 , figs. 4-6, 7-9, 10-12.

\section{Rugoglobigerina hexacamerata Brönnimann}

Rugoglobigerina reicheli hexacamerata Brönnimann, 1952a, pp. 23-25, pl. 2, figs. 10-12; text-figs. 8a-c, d-f, g-i, k-m.

\section{Rugoglobigerina macrocephala Brönnimann}

Rugoglobigerina macrocephala macrocephala Brönnimann, 1952a, pp. 25-27, pl. 2, figs. 1-3; text-figs. 9a-s.

\section{Rugoglobigerina milamensis Smith and Pessagno}

Rugoglobigerina milamensis Smith and Pessagno, 1973, pp. 56-57, pl. 24, figs. 4-7.

\section{Rugoglobigerina pennyi Brönnimann}

Rugoglobigerina rugosa pennyi Brönnimann, 1952a, p. 34, pl. 4, figs. 1-3; text-figs. 14a-c, d-f, g-i.

\section{Rugoglobigerina rotundata Brönnimann}

Rugoglobigerina rugosa rotundata Brönnimann, 1952a, pp. 34-36, pl. 4, figs. 7-9; text-figs. 15a-c, d-f; 16a-c.

\section{Rugoglobigerina rugosa (Plummer)}

Globigerina rugosa Plummer, 1926, pp. 38-39, pl. 2, figs. 10a, b, c, d. The specimens referred to this taxon include both four- and fivechambered forms, which vary considerably in the degree of increase in chamber size as added, in the relative size of the ultimate chamber, and the degree of development of meridionally arranged rugosities. As considered here (see also Smith and Pessagno, 1973, pp. 58-60), Rugoglobigerina rugosa subrugosa (Gandolfi), $R$. ornata subornata (Gandolfi), $R$. badryi El-Naggar, and $R$. browni El-Naggar are included in $R$. rugosa as variants or transitional forms.

\section{Ventilabrella multicamerata de Klasz}

Ventilabrella multicamerata de Klasz, 1953, p. 230, pl. 5, figs. 1a-b.

Ventilabrella riograndensis Martin

Ventilabrella riograndensis Martin, 1972, pp. 88-89, pl. 2, figs. 1, $2 a-b, 3,4 a-b$. 

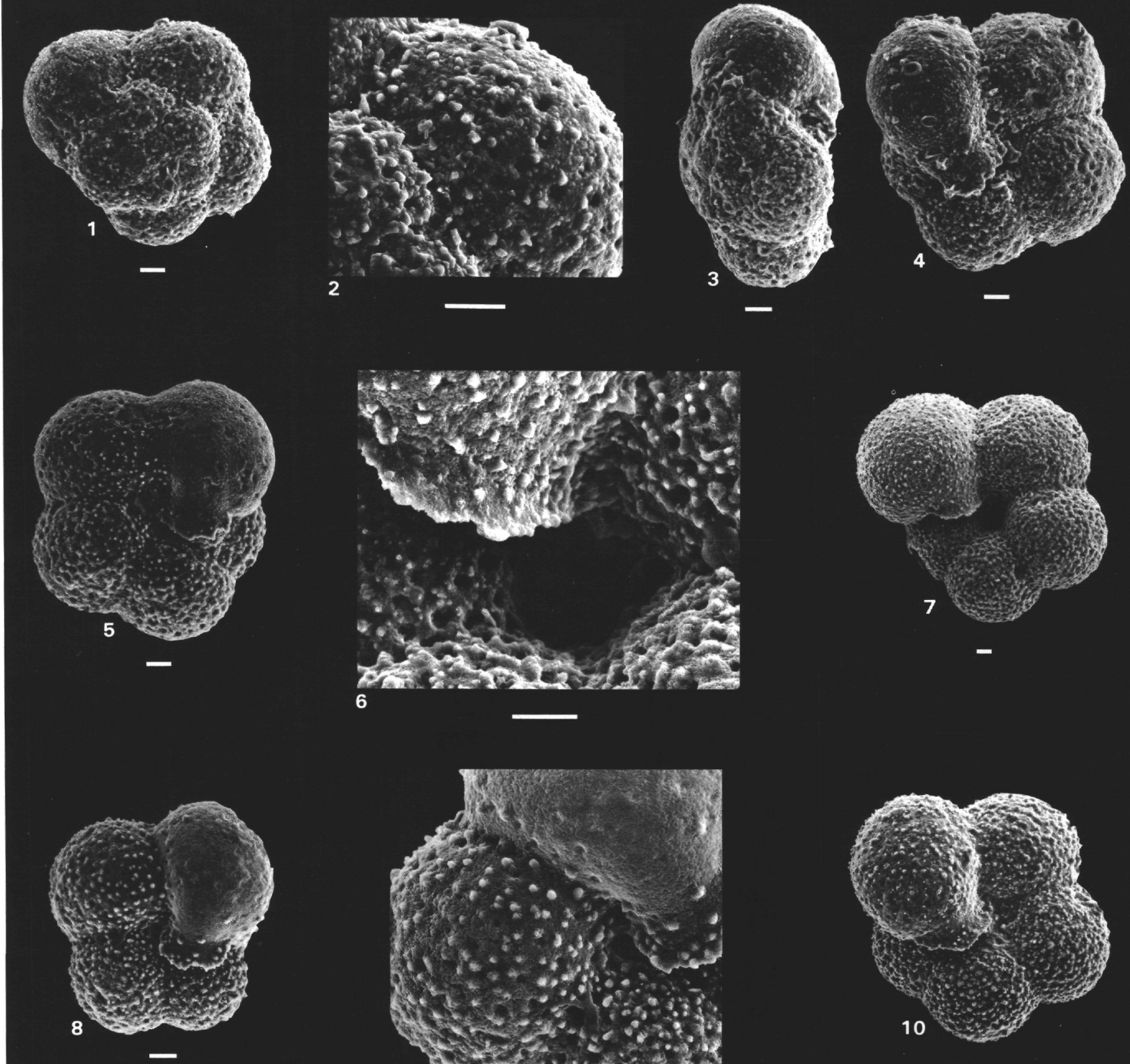

6
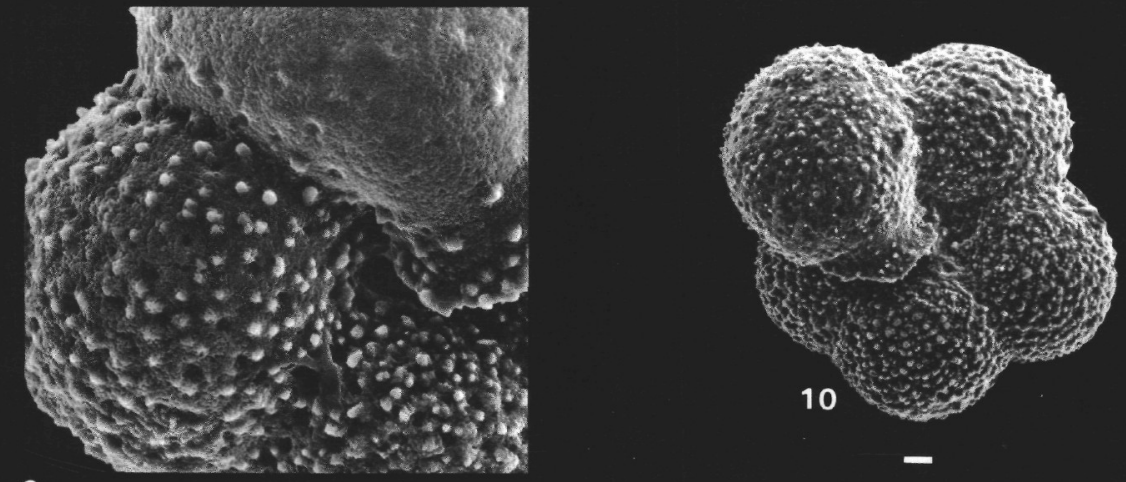

Plate 1. "Globigerina eugubina" Luterbacher and Premoli Silva (s.1.) from Hole 524. Scale bar is $10 \mu \mathrm{m}$ for all figures. Figs. 1 to 4 are from Sample 524-21-4, 26-28 cm. Figs. 5, 8, and 9 are from Sample 524-20,CC. Figs. 6, 7, and 10 are from Sample 524-20-3, 4-7 cm. 1. Spiral view. 2. Detail of penultimate chamber of Fig. 1. 3. Side view. 4 and 5. Umbilical views. 6. Detail of umbilical region of Fig. 7 . 7 and 8. Umbilical views. 9. Detail of umbilical region of Fig. 8. 10. Umbilical view. 